\title{
Powroty niemożliwe, powroty nieuniknione - konwencjonalność i topiczność w prozie Miriam Akavii
}

Miriam Akavia, urodzona w 1927 roku w Krakowie, zaczęła publikować w latach 70. w Izraelu, kiedy zbliżała się do pięćdziesiątego roku życia. Pisarka zawsze wyraźnie określała relacje między własną twórczością a egzystencją: „Moje życie jest w moich książkach. Pisanie służy mi do dokumentowania przeżyć" . Niepoddawane autorefleksji były przyczyny i efekty pisania (zależne od wewnętrznego przymusu „dania świadectwa”) oraz dobór środków ekspresji. Akavia nie ograniczała się do eksplorowania własnej biografii - spisywała historie zasłyszane, kompilując czasem opowieści z różnych źródeł. Podobnie nie poprzestawała na spisywaniu traumatycznych doświadczeń z czasów Holokaustu, pragnęła przywoływać pamięć o latach poprzedzających Wydarzenie, przede wszystkim jednak chciała zaświadczać o nieusuwalnych śladach, jakie pozostawiło na ocalałych. Izrael - wybrana ojczyzna - ukazywany był z reguły jako ich przystań, przystanek na drodze, miejsce spoczynku².

Ostatnia wydana przez Akavię książka, zatytułowana Moje powroty, miała charakter pożegnalny, nosiła znamiona złożonego w całość przesłania powstałego w wyniku „przeglądania szuflad”, zbierania tekstów niepublikowanych (lub publikowanych w innych okolicznościach), wykorzystywania zaniechanych pomysłów. Tematem głównym, ujawniającym się na poziomie przekazu tomu (jako całości), stały się owe „powroty” - do domu, ojczyzny, dzieciństwa. Eksplorowa-

\footnotetext{
${ }^{1}$ M. Akavia: Moje powroty. Kraków 2005, s. 11. Dalsze cytaty z książki opatrzone numerami stron podaję według tego wydania.

${ }_{2}^{2}$ Pisarka, urodzona jako Matylda Weinfeld, zmieniła nazwisko po przybyciu do Izraela. Zmarła w Tel Awiwie w 2015 r.
} 
nie pokładów pamięci posłużyło przede wszystkim ponownemu porządkowaniu doświadczeń, tym razem spisanych $\mathrm{w}$ języku polskim ${ }^{3}$. Zbiór, na który składają się utwory różne pod względem gatunku, charakteru i przeznaczenia, można potraktować jako przedśmiertną spowiedź oraz testament, zamykający ziemskie sprawy, a zarazem jako zestaw reprezentatywnych dla całego jej pisarstwa konwencji, ujęć i chwytów. Pojawiły się w nim po raz kolejny nie tylko fragmenty jej własnego życiorysu, ale i biografii wielu niepowiązanych ze sobą osób; pisarka często też uruchamiała perspektywę doświadczenia zbiorowego. Autorka wypowiadała się we wstępie w imieniu rozproszonych po świecie, ocalałych członków żydowskiej wspólnoty, stwierdzając jednoznacznie:

Trzy domy, trzy ojczyzny mają Żydzi z Polski żyjący gdzieś poza krajem w diasporze. Są lojalnymi i pełnoprawnymi obywatelami państw, w których mieszkają, choć modląc się, wypowiadają swą tęsknotę „na przyszły rok w Jerozolimie". Polska natomiast pozostaje dla nich domem rodzinnym, miejscem urodzenia, gdzie po raz pierwszy ujrzeli świat i uczyli się świata. Mają więc Żydzi z Polski trzy ojczyzny, a może nie mają ani jednej?

Sytuowała tym samym pozostających w diasporze Żydów w pozycji wiecznych wygnańców, pozbawionych „prawdziwego”, jednego domu4.

Dookreślała zarazem wyraźnie odmienność sytuacji tych, którzy po katastrofie zdecydowali się zamieszkać w Izraelu:

Z nami w Izraelu jest inaczej. Z przekonaniem, z determinacją chcemy mieć tylko jedną ojczyznę. Pragniemy jej służyć, pielęgnujemy w sobie patriotyczny zapał, dzisiaj już chyba niemodny. Chcieliśmy się odmienić, żyć inaczej niż nasi przodkowie. Ich życie pełne upokorzeń, i tragiczny koniec - odstraszały nas.

${ }^{3}$ Akavia pisała swoje utwory w języku hebrajskim, niektóre z nich tłumaczyła na polski (przełożyła zresztą wiele utworów literackich zarówno z hebrajskiego na polski, jak i z polskiego na hebrajski), by na koniec powrócić do języka dzieciństwa. Beata Tarnowska tak podsumowywała istotę szerszego zjawiska, w którego ramy wpisują się „pożegnania” Akavii: „Większość pisarzy imigrantów przybyłych z Polski lub imigrantów, którzy stali się pisarzami w nowej ojczyźnie, pozostała trwale związana z tradycją polskiej literatury. Dotyczy to zarówno twórców piszących tylko po polsku, jak i pisarzy dwujęzycznych, którzy po latach wrastania w nowy język i próbach tworzenia w nim literatury wracali do języka pierwszego, jakim był polski. Powrót ten nie oznaczał, rzecz jasna, całkowitego porzucenia hebrajskiego, a jedynie nową repartycję zadań i funkcji obu języków” (B. TARnowsKa: „Bejn polanit le’iwrit”. O polsko-hebrajskim bilingwizmie literackim w Izraelu (rekonesans). „Wielogłos” 2016, nr 2 (28), s. 118).

${ }^{4}$ Przekonanie to zostało powtórzone w opowiadaniu zatytułowanym Myckelby - jeden z bohaterów, który trafil po wojnie do Izraela, tak podsumowuje wybór kolegi zamieszkałego w Szwecji: „Czego mam zazdrościć? Nie jest ani Żydem, ani Polakiem, ani Szwedem. To stan wcale niegodny zazdrości” (s. 238). 
Topika domu, kluczowa dla twórczości Akavii, ulegała jednak wielorakim rozszczepieniom - deklaratywna przynależność do ,jedynej”, wybranej ojczyzny niejednokrotnie bywała waloryzowana przez afektywną więź z przestrzenią dzieciństwa. Temat zadomawiania się, oswajania obcych miejsc, rozpisany polifonicznie na doświadczenia jednostkowe, odsłaniał z reguły trud, jaki towarzyszył procesom zakorzeniania się w nowych realiach egzystencji. Niezwykle poruszające okazują się niezgodności pomiędzy tekstową realizacją potrzeby gloryfikowania nowej ojczyzny a koniecznością dokumentowania etapów wrastania w dotkliwie nieprzyjazną rzeczywistość. Podobnie rzecz się ma z niekoherencją pomiędzy krytycznym oglądem realiów Polski przed- i powojennej a obrazami szczęśliwego dzieciństwa.

Rozziew między racjonalnie dokonywanym wyborem a sferą pamięci wynikał z przemożnej siły wspomnień. Akavia stwierdziła: „Z biegiem lat okazało się jednak, że nie można odrzucić przeszłości. Ani tego, co było dobre, ani tego, co było złe" (s. 6). Pisarka kreśliła zatem przebieg meandrów własnej i cudzej pamięci, która zmuszała do powrotów do miejsc wcześniej usuwanych ze świadomości - tym samym pamięć, nieodłącznie związana z doświadczaniem przestrzeni, stała się przede wszystkim sferą przechowywania jej subiektywnych obrazów. Galeria postaci wyrwanych z własnego miejsca, ukazanych w rozmaitych odsłonach przymusowych powrotów do przeszłości, bohaterów nękanych przez bolesne przeżycia, poświadczać miała przede wszystkim skalę destrukcji dawnych porządków i całego realnego świata, jaka dokonała się w ramach europejskiej cywilizacji w czasie wojennego kataklizmu.

Izrael, a przede wszystkim kibuce stały się w twórczości Akavii specyficzną przestrzenią próby. To oczywiście miejsca, które tworzyli i uznawali za własne przedwojenni osadnicy. Okazywały się jednak często także nie-miejscem dla powojennych przybyszów z Europy, niepotrafiących zaakceptować reguł panujących w osadniczych wspólnotach. W opowiadaniu Sześcioro ich było radosna wieczorna zabawa w takt piosenki o słowach: „Praca jest naszym życiem, ona nas oswobodzi", budziła w byłych więźniach obozów koncentracyjnych chęć odseparowania się i głęboką konsternację. Jeden z nich podsumował: „Wesoło im tam [...] Te słowa nie wywołują u nich żadnych skojarzeń" (s. 199). Kibuc nie mógł stać się domem dla tych sześciorga ocaleńców: po kolei opuszczali wspólnotę, dla której pozostali „obcymi”, niemożliwymi do zaakceptowania przez zbiorowość, bo odmawiającymi podporządkowania się prawom - przypadkowego w istocie $\mathrm{z}$ ich punktu widzenia - miejsca zamieszkania.

Pragnienie, by pisać o nowej, izraelskiej ojczyźnie, splotło się w twórczości Akavii $\mathrm{z}$ wewnętrznym przymusem (zrodzonym podczas pierwszej powojennej podróży do Polski) opowiadania o tym, jaki „przepiękny był tutaj mój krakowski DOM” (s. 8). Pisarka deklarowała: „Chociaż niemodna, zostanę tym, kim jestem. A jestem już na zawsze krakowskim dzieckiem, osieroconym z rodziny i z ojczyzny, dzieckiem, które znalazło izraelską ojczyznę i stara się wiernie jej 
służyć" (s. 11-12). Perspektywa dziecięca tłumaczy po części zarówno żarliwość deklaracji wierności nowej ojczyźnie, jak i nieprzepracowaną żałobę po stracie tej pierwszej, której przechowywane wizje ograniczone były przez horyzont poznawczy młodej dziewczyny do mieszkania w krakowskiej kamienicy, podwórka, szkoły i miasta dzieciństwa. Istotne jest to, co pomiędzy: niewyrażalna w swej istocie trauma, wyrwa w biografii - zagłada znanego, zrozumiałego świata, przeżyta na tym etapie życia, kiedy jeszcze dziecko nie buntuje się przeciw dorosłym, nie wypróbowuje samodzielnych dróg do zyskania samoświadomości, nie dąży do subwersywnej autoidentyfikacji, na przekór rodzicom, dziadkom, nauczycielom 5 .

Naznaczenie biografii traumą prowadzi z reguły do swoistego „unieruchomienia" wspomnień szczęśliwego dzieciństwa oraz relacji z bliskimi - jak pisała Karolina Famulska-Ciesielska: „[...] relacja zerwana w dzieciństwie ma szczególny, idealny, nieskażony kształt, bardzo rzadko występujący w normalnej biografii, której nie naznaczyło tak brutalne załamanie"6. Podobnie podsumowywał pisarstwo Akavii Henryk Grynberg - było ono dla niego „powrotem z ucieczki - do pięknego domu rodzinnego, ocalonego w pamięci [...] Akavia należy do polskiej literatury Szoa. Ani Izrael, ani hebrajski język od tego jej nie uchronił"7. Tym samym stały motyw twórczości pisarki - powrót do domu dzieciństwa - zastygły w rozpoznawalnym i nienaruszalnym kształcie, uznany został za esencję jej prozatorskich prób, przybliżeń, poszukiwań.

Topos jako kategoria badań literackich w zaproponowanym przez Janinę Abramowską rozumieniu - czyli rezultat petryfikacji tradycyjnego motywu ${ }^{8}$ - oraz wskazane przez badaczkę elementy topiki domu jako miejsca, które reprezentuje niepodważalne wartości, warte podtrzymywania, odzyskania lub restytucji ${ }^{9}$, nie straciły interpretacyjnej przydatności. Paweł Wolski z kolei uznał, że topos/ topika oprócz wielu przypisywanych im znaczeń stanowią narzędzia dające możliwość „bezkonfliktowego godzenia rozmaitych narracji” oraz są „użytecznym i precyzyjnie sprofilowanym aparatem badań narracji holokaustowych"10. Topiczne ujmowanie motywu domu rodzinnego oraz domu-ojczyzny służyło Akavii do osadzania się w pozagładowej rzeczywistości, odnajdywania własnego miejsca w świecie, na przekór przeżytej w dzieciństwie traumie.

${ }^{5}$ Akavia tak wspomina rodziców: „Kochałam oboje. Nie zdążyłam doznać okresu buntu przeciw rodzicom, nie toczyłam z nimi sporów. Tylko tęsknoty za nimi doznałam” (s. 44).

${ }^{6}$ K. Famulska-Ciesielska: Polacy, Żydzi, Izraelczycy: tożsamość w literaturze polskiej w Izraelu. Toruń 2008, s. 134.

7 H. Grynberg: Pokolenie Szoa. „Odra” 2002, nr 4, s. 47-48.

${ }^{8}$ Zob. J. Abramowska: Topos i niektóre miejsca wspólne badań literackich. „Pamiętnik Literacki" 1982, z. 1-2, s. 3-23.

9 Zob. J. Abramowska: Peregrynacja. W: Taż: Powtórzenia i wybory. Studia z tematologii i poetyki historycznej. Poznań 1995, s. 294-340.

${ }^{10}$ P. Wolski: Myśli różne o ogrodach (koncentracyjnych). „Narracje o Zagładzie” 2016, nr 2, s. 9. 
Tom Moje powroty odsłania również (wyraźniej chyba niż poprzednie książki) ciążenie pisarstwa Akavii ku konwencjonalności, osłabiającej z pewnością siłę artystycznego wyrazu spisywanych przez nią opowieści ${ }^{11}$. Beata Przymuszała tak postrzega tę kwestię:

Problemem nie jest więc sama literackość opisu doświadczenia, lecz jej szczególny przypadek, czyli konwencjonalność ujęcia. Posługiwanie się stylistycznymi kliszami, wykorzystywanie mocno utrwalonych form wypowiedzi było i jest często źródłem zarzutów zarówno o wpisywanie Zagłady w ciąg wydarzeń, o których można mówić za pomocą znanych języków (pozbawiając ją tym samym wyjątkowego charakteru), jak i o artystyczną podrzędnośćc ${ }^{12}$.

Badaczka jednak udowadnia, że przyczyną owej konwencjonalności może być pragnienie poświadczenia prawdy zawartej w opowieści. Mówienie poprzez konwencje stawało się tym samym - także dla izraelskiej pisarki - sposobem nawiązywania kontaktu z odbiorcą na płaszczyźnie zrozumiałych metafor i obrazów $^{13}$. Nieporadność kompozycyjna, stylistyczne niedostatki, niedopowiedzenia i schematyczność ujęcia mogą zostać uznane z tej perspektywy za gwarancję autentyzmu zapisywanych przeżyć. Konwencjonalność i topiczność prozy Akavii z jednej strony zdają się „więzić” doświadczenie (ograniczać ekspresję i drogi literackiego transmitowania przeżyć), z drugiej zaś zmuszają do skupienia uwagi na jednostkowym wysiłku budowania (odbudowywania) tożsamości.

W otwierającym zbiór tytułowym utworze, powstałym jeszcze w 1994 roku, padło wyznanie:

Zaraz po wojnie myślałam, że moja noga już nigdy nie postanie na polskiej ziemi. A teraz wracam tutaj jak do domu. Dzisiaj wiem już z całą pewnością, że Kraków stanowi najbardziej znaczącą część mojego życia i że nie mogę go pominąć, wykreślić, czy zapomnieć [...] tych jedenaście lat w Krakowie nasyconych jest życiem wielu pokoleń całej mojej rodziny, zarówno ze strony ojca, jak i ze strony matki.

${ }^{11}$ W haśle osobowym poświęconym Akavii Sławomir J. Żurek tak charakteryzował jej twórczość: „Proza ta stanowi ciekawy przykład literatury z pogranicza beletrystyki, osobistego świadectwa i literatury faktu" (S.J. ŻureK: Miriam Akavia. W: Leksykon kultury polskiej poza krajem od roku 1939. T. 1. Red. K. Dyвciak, Z. Kudelski. Lublin 2000, s. 7). W istocie należałoby podkreślić, że jest to tradycyjna w swym kształcie proza wspomnieniowa, która staje się „ciekawa” ze względu na materię spisywanych doświadczeń.

${ }_{12}$ B. PrzymuszaŁa: Smugi Zagłady. Emocjonalne i konwencjonalne aspekty tekstów ofiar i ich dzieci. Poznań 2016, s. 16.

${ }^{13}$ Tak można odczytywać np. fragment opowiadania Białe noce i słowa narratorki: „Zrobiło mi się smutno, bardzo smutno. Przypomniałam sobie tamtą tragiczną inną planetę, gdzie, nie tak dawno temu, palono miliony niewinnych ludzi. Ta inna planeta była w samym sercu Europy. Przypomniałam sobie siebie samą, rzuconą tam na stos, jak myślałam wtedy z bólem, że wszyscy o nas zapomnieli, że nikomu nie zależy" (s. 250-251). 
Dom - ten pierwszy, najważniejszy - choć bezpowrotnie utracony miał niemal magiczną siłę przyciągania: stale obecny w pisarskiej aktywności i pamięci Akavii przyzywał także do odwiedzin $\mathrm{w}$ rodzinnym mieście $\mathrm{w}$ porządku jej biografii. Wraz z upływem czasu zmieniał się nie tyle odtwarzany po wielokroć obraz krakowskiego dzieciństwa, ile sposoby odczytywania, interpretowania czy nawet projektowania wizji przeszłości.

Autobiograficzne świadectwo Miriam Akavii zdaje się w pełni potwierdzać rozpoznanie Małgorzaty Czermińskiej, że istnienie i pozostawanie sobą $\mathrm{w}$ odniesieniu do miejsc nie jest równoznaczne z pozostawaniem $\mathrm{w}$ bezruchu i bezczasie. Przestrzeń fizyczna trwa, lecz zmieniają się jej znaczenia, symbolika, materialna zawartość i wypełniające ją ludzkie doświadczenie. Z perspektywy pojedynczej egzystencji przestrzeń pamięci bywa z reguły sferą czynnej ingerencji w przeszłość:

Przemijanie w miejscu nie równa się całkowitemu znikaniu raz na zawsze. Nie tylko archeologowie, którzy naprawdę kopią w glinie i piachu, potrafią znaleźć szczątki świadczące o minionych czasach. Archeologowie wyobraźni również odnajdują (współtworząc je zarazem) kolejne warstwy sensu, kolejne ślady ${ }^{14}$.

Akavia - choć dopiero po upływie trzech dekad przeżytych w nowej ojczyźnie - świadomie kreowała obrazy własnych relacji z miejscami z przeszłości. Nie tylko poświęcała uwagę ich pieczołowitemu odtwarzaniu $\mathrm{w}$ tekstach, ale skupiała się na nasycaniu narracji jednostkowym (choć nie zawsze osobistym) doświadczeniem. Przede wszystkim jednak usiłowała wydobyć wizje przedwojennego domu z nakładającej się na wspomnienia wiedzy o przyczynach i skali destrukcji utraconego świata.

Krakowski dom nie mógł tym samym stać się dla pisarki wyłącznie konwencjonalną przestrzenią szczęśliwego dzieciństwa, choć ten właśnie obraz stanowił ośrodek jej literackich kreacji, chronioną za wszelką cenę wartość, odblask nieistniejącego, utraconego bezpowrotnie własnego „miejsca na ziemi”. We wspomnienia o rodzinnym szczęściu, dostatku i powodzeniu nieuchronnie wkradały się elementy traktowane jak zwiastuny nadchodzącej tragedii czy raczej znaki, rozpoznawane $\mathrm{w}$ tej funkcji z perspektywy mijającego czasu i rosnącej wiedzy o Zagładzie. Akavia wspominała: „Nie rozumiałam wtedy smutku i niepokoju moich rodziców. Wiem z całą pewnością, że byli przywiązani do miasta, w którym oboje się urodzili, i kochali je. Dzisiaj rozumiem, że nie czuli się w nim pewnie" (s. 28). Zrozumienie po latach szerszego tła dziecięcych wspomnień pozwalało zarazem na dokładniejsze ich katalogowanie oraz na procesualne dookreślanie zrębów własnej tożsamości. Dziewczynka z przedwojennego Krakowa została przecież podczas wojny „prawie że zabita” (s. 29). Akavia mówiła wprost:

${ }^{14}$ M. Czermińska: Tożsamość kształtowana w pamięci miejsca. W: Kulturowa historia literatury. Red. A. ŁebKowska, W. Bolecki. Warszawa 2015, s. 148. 
[...] ręka, która kreśli te słowa, należy do innej osoby, do kogoś, komu dane było z tej marnej ocalałej cząsteczki rozpocząć inne życie. To inne życie im bardziej wzbudza we mnie poczucie przynależności i im bardziej zwraca mi niejaką pewność siebie - tym bardziej dyktuje: nie zapomnieć, niczego nie zapomnieć.

Nakaz, by „niczego nie zapomnieć”, był równoznaczny z najgłębszą potrzebą, by dawać świadectwo, zapisywać ułamki przeżyć, rejestrować minione zdarzenia, choćby były najbardziej codzienne, zwyczajne, przyziemne ${ }^{15}$.

W drugiej połowie XX wieku zmieniający się status świadectw literackich naruszył wcześniejsze hierarchie tekstów, a one same wykroczyły poza obręb dotychczasowych form dyskursu kulturowego. Przypominając, że poszukiwanie śladów pamięci $\mathrm{w}$ miejscach, znakach i przedmiotach nabrało szczególnego znaczenia pod wpływem wojennej katastrofy cywilizacyjnej, Maria Delaperrière pisała o literaturze Holokaustu i jej statusie:

[...] do dziś zmaga się z publiczną amnezją, przybierającą czasem drastyczną formę negowania prawdy. Stwierdzenie, że nic takiego nie miało miejsca, jest [...] kluczem do problemu nielegalności, braku legitymizacji opisywanych wypadków. Tragedia obozów Zagłady, niewyrażalna sama w sobie, jest tym trudniejsza do przekazania, że odnosi się do miejsc, które istniały i których już nie ma, stały się miejscami paradoksalnymi ${ }^{16}$.

Akavia w swojej twórczości przeciwstawiała się i publicznej amnezji, i próbom ostatecznego zatarcia pamięci o miejscach naznaczonych zbiorowym, niewyobrażalnym cierpieniem. W jej pisarstwie odtwarzanie fragmentów przestrzeni pozostaje swoistym „umiejscowieniem” żydowskiego losu, którego częścią stały się dzieje jej rodziny. Przypominała nieustannie, że jej dom przy ulicy Łobzowskiej BYŁ, podobnie jak BYŁ obóz Kraków-Płaszów. Przeciw wszelkim próbom usuwania ze zbiorowej świadomości pamięci o Zagładzie wystawiała własną, kruchą pamięć o przestrzeniach naznaczonych tragedią wspólnoty: rodzinnej, koleżeńskiej, sąsiedzkiej.

Dla autorki Moich powrotów szczególnie bolesna okazywała się zaakceptowana przez polską społeczność nieobecność Żydów w miejscach, w których żyli od pokoleń: „Nie ma nas w Krakowie i nie ma nas w innych miastach Polski. Zniknęliśmy stąd na zawsze - opuszczony, zamęczony naród” (s. 29).

${ }^{15}$ Wśród wielu takich wspomnień znajduje się np. obrazek wizyt w sklepie cioci, która zawsze częstowała dziewczynkę słodyczami, m.in. „kostkami Domańskiego”. W pamięci zachowały się też słowa: „Nie kupujemy już czekolady Wedla - powiedziała raz ciocia, częstując mnie kostkami - to wielki antysemita..." (s. 24).

${ }^{16}$ M. Dela Perrière: Miejsca pamięci czy pamięć miejsc. Kilka refleksji na temat uobecniania przeszłości w literaturze współczesnej. W: Kulturowa historia literatury..., s. 167. 
Przeobrażenia dawnych przestrzeni, zacieranie śladów żydowskiej obecności, likwidowanie terenów gett i cmentarzy, niszczenie miejsc kaźni miało ułatwiać i częstokroć ułatwiało manipulacje w sferze zbiorowej pamięci. Tak można postrzegać powojenne dzieje terenu po obozie w Krakowie-Płaszowie, w którym rozpoczęła się wojenna gehenna nastoletniej Matyldy, a który pozostał miejscem niemożliwym do usunięcia z pamięci. W opowieści Ich groby sa jedynie we mnie powrócił obraz ostatniego spotkania z ojcem, który przyznał wówczas, że ponosi winę za tragiczny los rodziny, to on bowiem nie zgodził się na planowany przez matkę wyjazd do Palestyny:

Ostatni raz widziałam ojca w obozie w Płaszowie. Staliśmy po dwóch stronach kolczastego drutu. Głodni i wymęczeni. Moje myśli koncentrowały się wokół nadziei, że wytrzaśnie jakiś kawałek chleba i poda mi przez druty [...] Miałam wtedy czternaście lat, chciałam go pocieszyć, chciałam powiedzieć, że to nie jego wina - ale nie wiedziałam, jak to powiedzieć, i nic nie odparłam.

W obozowej rzeczywistości to nieme pożegnanie córki z ojcem wytyczało zarazem możliwą, choć niespełnioną historię domu, który ocalałby, gdyby został na czas przeniesiony w odległą, nieznaną krainę.

W artykule Pryzma - zrozumieć nie-miejsce pamięci Roma Sendyka tak opisuje dzieje krakowskiego miejsca kaźni:

Po wojnie teren pozostał niezabudowany i niezagospodarowany, samorzutnie odtwarzająca się roślinność wzięła odwet za czas niemal całkowitego zdegradowania z okresu działania obozu. [...] Zdjęcia satelitarne pokazują pusty krater w tkance miasta, prawie tej samej wielkości, co licznie odwiedzane przez turystów krakowskie Stare Miasto: obie te plamy pozostają w stosunku do siebie jak bliźniacze kleksy testu Rorschacha, wcielając miejskie świadome i nieświadome, widzialne i niewidzialne, pokazywane i ukrywane, oswojone i niesamowite ${ }^{17}$.

Swoisty, wielorako „zmieszany” charakter nie-miejsc pamięci zmusił badaczkę do poszukiwania terminologicznej metafory dla "nieporządku pozostającego w stanie ciągłego poruszenia i zmiany”. Stąd "pryzma” jako termin adekwatny do tego, co do dziś pozostało po obozie w Płaszowie, pozwalający dostrzec, że jest to obiekt „dekonstruujący wszelkie wyobrażenia homogenizujące jego jakości: rozprasza, komplikuje pozorną monologiczność dyskursu”18.

Tom Moje powroty także ma charakter literackiej „pryzmy”. Przywołane w nim opowieści o losach własnych i cudzych prowadzą do specyficznego

${ }^{17}$ R. Sendy ka: Pryzma - zrozumieć nie-miejsce pamięci. W: Inne przestrzenie, inne miejsca. Mapy i terytoria. Red. D. Czaja. Wołowiec 2013, s. 282.

${ }^{18}$ Tamże, s. 286. 
uszczegółowienia dominującego dyskursu Zagłady. Skupienie uwagi na z pozoru nieznaczących szczegółach czy pozostających poza głównym nurtem rekonstrukcji Wydarzenia jednostkowych doświadczeniach wiedzie do poszerzenia oglądu przeszłości, a zarazem pozwala ujrzeć Historię w mikroskali - z perspektywy dziewczynki, która utraciła swój krakowski dom i choć zamieszkała w nowym, nigdy nie potrafiła usunąć z pamięci obrazu tego pierwszego. Akavia, pisząc o utracie całego majątku rodzinnego, wspominała: „[...] tylko srebrna cukiernica, którą wyprosiła dla siebie będąca z wizytą w Polsce ciocia Chalucka w 1938 roku i zabrała ze sobą do Palestyny, tylko ona ocalała" (s. 38). Okruch rodzinnego domu, synekdochicznie potraktowany przedmiot, został przypadkiem ocalony, ponieważ trafił do miejsca, w którym później powstało izraelskie państwo. I ta właśnie cukiernica - przechowywana jak skarb w mieszkaniu krewnej - pozostaje widomym znakiem zarówno niepowetowanej, olbrzymiej straty, jak i możliwości ułamkowego, cząstkowego jej przezwyciężenia.

Podobnie odczytać można obrazek z roku 2000 ze starego cmentarza żydowskiego $\mathrm{w}$ Krakowie, zapis zdarzenia zaledwie prawdopodobnego, a jednak znaczącego - w podwójnym, negatywnym i pozytywnym sensie. Przypadkową rozmowę młodych uczestników wycieczek z Izraela i USA z porządkującym groby Polakiem kończy konkluzja: „Nad starym żydowskim grobem stali razem Dalia, Piotr i Joy, nie wiedząc, że stoją nad grobem wspólnego pradziada" (s. 262). Młodzi ludzie, nieświadomi swego pokrewieństwa, są bliscy odkrycia ich wspólnych więzów - dlatego że znają opowieści o przodkach i akceptują swoją rodzinną przynależność. Stary - ocalały z wojennej zawieruchy - grób staje się miejscem spotkania potomków z ocalonych, żywych i rozrastających się gałęzi rodu. Ich domy, choć rozrzucone po różnych kontynentach, trwają.

Utwory Miriam Akavii, z reguły proste, nakierowane na odbiorcę (,czytelnika naiwnego"?), dydaktycznie nacechowane, skupiają się na rejestrowaniu śladów tego, co ocalone, i tego, co ocalające. Ulrich Baer w artykule Umiejscowić pamięć... stwierdził: „Paradoksalnie zdarza się, że naukowe, artystyczne i medialne zainteresowanie Holokaustem przesłania, a nawet blokuje rozumienie jego wpływu na wszelkie formy praktyki kulturowej”19. Obraz Zagłady, skutecznie ramowany i reprezentowany $w$ niezliczonych tekstach kultury, zaczyna przesłaniać istotę cywilizacyjnej katastrofy. Podobne skutki przynosi zalew kiczu holokaustowego w kulturze popularnej. Baer podkreślał:

Holokaust, niebędący zagrożeniem dla wyobraźni, zmienia się w przydatny ekran do autoanalizy. Toczone przez lata spory na temat niemożności pogodzenia Holokaustu i reprezentacji oraz rozumienia nie są obecnie uznawane

${ }^{19}$ U. BAeR: Umiejscowić pamięć: współczesna fotografia. Holokaust i tradycja pejzażu. Przeł. R. Sendyka. W: Pamięć i afekty. Red. Z. Budrewicz, R. Sendyka, R. Nycz. Warszawa 2014, s. 256. 
jako nieodłączne od samej katastrofy, lecz są postrzegane - coraz częściej i niesłusznie - jako kwestie wyłącznie akademickie ${ }^{20}$.

Dla Akavii, zmagającej się ze świadomością, że jej twórczość nie jest zbytnio ceniona $^{21}$, właśnie autoanaliza, próby zrozumienia własnego i wspólnotowego losu oraz rejestrowanie przebiegu trudnego procesu zadomawiania się w świecie stały się zadaniem nadrzędnym, oddzielonym od namysłu nad artystycznym kształtem wypowiedzi czy ontologicznymi i epistemologicznymi kontekstami Wydarzenia. W obranym spektrum natężenia głosu świadka (ściszonej, dystansującej się relacji) potrafiła jednak - jakby mimowolnie - uświadamiać odbiorcom skalę destrukcji świata po Zagładzie: w perspektywie pojedynczego losu i osobistych poszukiwań egzystencjalnej równowagi.

Miriam Akavia postrzegała siebie przede wszystkim w roli - wykorzystującego, co prawda, wszelkie ułatwienia fabularne, narracyjne, kreacyjne - łącznika między odchodzącym, minionym czasem a przyszłością, dla której należy pozostawić ślad przeszłości, by nie zatarła się pamięć o najtragiczniejszych doświadczeniach wspólnoty:

Ich groby są jedynie we mnie. Między ich grobami zakiełkowało życie moich córek. Było we mnie i żywe, i martwe. Potem dzieci moje opuściły te groby, by żyć własnym życiem. Jestem przy nich, jestem z nimi, a we mnie wciąż jeszcze cmentarz mojej poprzedniej rodziny, która nie ma poza mną innego grobu.

Pisarka przynależała do pokolenia, któremu zrazu nie dane było w Izraelu odsłaniać własnych przeżyć, później zaś jego doświadczenie bywało częstokroć spychane na margines rodzącej się i świadomie wytwarzanej zbiorowej tożsamości. Stąd nieraz powtarzane deklaracje: „Cokolwiek się stanie, niesiemy ze sobą zawsze i wszędzie - także w Izraelu - nasze żydowskie, różnorakie, nasiąknięte wieloma kulturami dziedzictwo. I naszą tragiczną przeszłośc” (s. 6). Podjęcie działań pisarskich skupionych na dokumentowaniu przeszłych zdarzeń nie było dla Akavii wyborem artystycznym (ideologicznym, politycznym), lecz egzystencjalnym.

Rozdwojona topika domu - tego utraconego i tego budowanego z zaangażowaniem oraz poświęceniem - sprawia, że twórczość Miriam Akavii należy rozpoznawać także w szerszym kontekście dyskursywnym, widocznym we współczesnych badawczych tendencjach. Uznanie europejskości Żydów łączy

20 Tamże, s. 257.

${ }^{21}$ Pisarka tak oceniała w 1994 r. status swojej „dokumentacji przeżyć”: „W Izraelu niestety ta forma twórczości nie jest zbyt wysoko ceniona. Niewielu traktuje ją jako coś, co wzbogaca izraelską literaturę. Nie jest dziś modne to, co piszę. Dlatego tak ważna była dla mnie ubiegłoroczna nagroda państwowa za pracę twórczą w dziedzinie literatury, którą otrzymałam z rąk premiera Rabina" (s. 11). 
się w obecnym czasie z dążeniem do prowadzenia pogłębionych rozważań nad teoretyczno- i historycznoliterackimi aspektami literatur europejsko-żydowskich. Jak stwierdza Eugenia Prokop-Janiec, tendencja ta ma dziś „charakter próby późnego zadośćuczynienia za wykluczenie i wypędzenie. W pewnym sensie jest to również spóźniona europejska odpowiedź na żydowski dyskurs udziału, dyskurs zadomowienia w Europie i przynależność do europejskiego społeczeństwa" ${ }^{22}$. Utwory Akavii powinny znaleźć właściwe miejsce w historii literatury polsko-żydowskiej jako jej wyrazisty, jednostkowo nacechowany głos ${ }^{23}$. Służyłoby to $\mathrm{z}$ pewnością przeciwdziałaniu współczesnym procesom przyzwolenia na usuwanie dużych obszarów historycznego doświadczenia ze sfery wspólnotowej pamięci.

Doświadczenie „wykluczenia wśród swoich”, niemożność artykułowania holokaustowych przeżyć w pierwszych latach istnienia Izraela (co stało się udziałem także Akavii) nie osłabiły potrzeby zwerbalizowania wspomnień, tylko opóźniły jej tekstowe realizacje. Robert Traba w artykule Procesy zbiorowego pamiętania i zapominania... dowodził:

Zapominanie, podobnie jak zapamiętywanie, może być skuteczne, a nawet pożyteczne, ale tylko w ograniczonym czasie. Wymaga ciągłego redefiniowania i poszukiwania optymalnej przestrzeni funkcjonowania, by nie stać się nakazem ideologicznego myślenia, lecz jedynie wpływać doraźnie na pozytywne identyfikacje wspólnoty z przeszłością ${ }^{24}$.

Powojenne mechanizmy „zapominania” - zarówno w Polsce, jak i w Izraelu związane z pragnieniem „otwarcia nowego rozdziału” oraz usunięcia przeszkody w postaci niepojmowalnego doświadczenia zbiorowego - mogły potwierdzać swoją ograniczoną przydatność jedynie w pierwszym okresie tworzenia izraelskiej tożsamości. Z kolei w Polsce mechanizm ten, od początku upodrzędniony wobec ideologicznej przemocy nowej władzy, do dziś objawia swój destrukcyjny charakter.

Opowieści spisywane przez Akavię poświadczają, że pamięć musi pozostać aktywnym elementem w przestrzeni identyfikacji i konstruowania tożsamości, zarówno jednostkowej, jak i wspólnotowej. Powroty niemożliwe - do miejsc już

${ }^{22}$ E. Prokop-Janiec: Warsztat historyka literatury pogranicza. Na przykładzie badań nad literatura rosyjsko-żydowska. W: Kulturowa historia literatury..., s. 135.

${ }^{23}$ Podobnie rzecz ujmował Jacek Leociak już w 1994 r.: „Polscy Żydzi są w Izraelu Izraelczykami. Są w swoim państwie, o które niejednokrotnie walczyli z bronią w ręku. Literatura pisana po polsku w Izraelu - obok krajowej i emigracyjnej - stanowi jakby trzeci stan skupienia. Zachowując swą niepowtarzalną tożsamość polsko-żydowskiego doświadczenia losu, wpisuje się w niepodzielną całość literatury polskiej poprzez wspólnotę języka i kulturowych tradycji” (J. Leociak: Na obu brzegach. „Nowe Książki” 1994, nr 3, s. 70).

${ }^{24}$ R. Traba: Procesy zbiorowego pamiętania i zapominania. Trzy przypadki i ich konsekwencje dla badania pamięci zbiorowej. W: Pamięć i afekty..., s. 391. 
nieistniejących i startych z powierzchni ziemi - okazują się tym samym powrotami koniecznymi, a nawet nieuniknionymi. Powroty takie są podróżowaniem w głąb, poprzez pokłady przeszłości, po to, by zrozumieć teraźniejszość i otworzyć się na przyszłość. Pojmowane metaforycznie, jako wędrówki w przestrzeni pamięci, umożliwiają odnalezienie i zaakceptowanie własnego miejsca na ziemi.

Według izraelskiej pisarki także realne podróże mogły, paradoksalnie, ułatwiać zakorzenianie się w świecie i w ojczyźnie. Nie musiały ograniczać się do poszukiwania zatartych śladów przeszłości czy rejestrowania zmian zachodzących w znanych dawniej miejscach (często bolesnych dla odwiedzającego). Pozwalały natomiast oderwać się od doraźnych kłopotów, problemów codzienności, zyskiwać dystans i poszerzać perspektywę oglądu własnego istnienia. Akavia pisała:

My, Izraelczycy, mamy kompleksy ludzi, którzy długi czas pozbawieni byli wolności, a i teraz są jakby zamknięci. Na pewno dlatego tak bardzo lubimy podróżować. Lubimy wsiąść do samolotu (pociągiem nie możemy wyjechać z naszego kraju) i wyfrunąć z naładowanego dynamitem rejonu w szeroki wolny świat. Lubimy odetchnąć innym powietrzem i odczuć wielkie przestrzenie.

Dobrowolne opuszczanie domu służyć miało przede wszystkim wytchnieniu i zapomnieniu, podróże były bowiem sposobem, by przez krótki czas nie pamiętać o „morzu nienawiści, które nas otacza”, zapomnieć o „wyjątkowości” żydowskiego losu i czuć się wówczas "na równi z innymi, być jednymi z wielu” (s. 243-244). Zdaniem pisarki prawo do własnego państwa można było odczuwać także jako wyrok uwięzienia na małym, zbyt ciasnym skrawku przestrzeni ${ }^{25}$. Wtedy właśnie szczególnie przydatna okazuje się nie tylko pamięć o innych przestrzeniach, innych miejscach, ale i możliwość realnej konfrontacji z tym, co nowe, odmienne, nieoswojone lub przekształcone przez upływ czasu. Dla Miriam Akavii wyzwoleniem $\mathrm{z}$ dawnego, tragicznego żydowskiego losu było posiadanie ojczyzny, którą można swobodnie opuszczać, by zawsze móc do niej wracać.

\section{Bibliografia}

Abramowska J.: Peregrynacja. W: J. Abramowska: Powtórzenia i wybory. Studia z tematologii i poetyki historycznej. Poznań 1995, s. 294-340.

${ }^{25} \mathrm{~W}$ opowiadaniu Życie i śmierć jednego z nas bohater wypowiada gorzkie słowa: „Większość narodów głosowała za prawem Żydów do własnego państwa, do małego kraju na zapomnianej, opuszczonej i zaniedbanej ziemi, która jak tylko odżyła, stała się od razu miejscem starć i sporów. Nie mamy szczęścia” (s. 169). 
Abramowska J.: Topos i niektóre miejsca wspólne badań literackich. „Pamiętnik Literacki" 1982, z. 1-2, s. 3-23.

Akavia M.: Moje powroty. Kraków 2005.

BAER U.: Umiejscowić pamięć: współczesna fotografia, Holokaust i tradycja pejzażu. Przeł. R. Sendyka. W: Pamięć i afekty. Red. Z. Budrewicz, R. Sendyka, R. Nycz. Warszawa 2014, s. 245-284.

Czermińska M.: Tożsamość kształtowana w pamięci miejsca. W: Kulturowa historia literatury. Red. A. ŁeвкоwskA, W. Bolecki. Warszawa 2015, s. 145-160.

Delaperrière M.: Miejsca pamięci czy pamięć miejsc. Kilka refleksji na temat uobecniania przeszłości w literaturze współczesnej. W: Kulturowa historia literatury. Red. A. ŁebKowska, W. Bolecki. Warszawa 2015, s. 161-172.

Famulska-Ciesielska K.: Polacy, Żydzi, Izraelczycy: tożsamość w literaturze polskiej w Izraelu. Toruń 2008.

Grynberg H.: Pokolenie Szoa. „Odra” 2002, nr 4, s. 37-49.

LeOCiAK J.: Na obu brzegach. „Nowe Książki” 1994, nr 3, s. 70-71.

Prokop-Janiec E.: Warsztat historyka literatury pogranicza. Na przykładzie badań nad literatura rosyjsko-żydowska. W: Kulturowa historia literatury. Red. A. ŁeBKowsKa, W. BOLECKI. Warszawa 2015, s. 133-144.

PrzymuszaŁa B.: Smugi Zagłady. Emocjonalne i konwencjonalne aspekty tekstów ofiar i ich dzieci. Poznań 2016.

Sendyka R.: Pryzma - zrozumieć nie-miejsce pamięci. W: Inne przestrzenie, inne miejsca. Mapy i terytoria. Red. D. CzajA. Wołowiec 2013, s. 278-299.

TARNOwsKA B.: „Bejn polanit le iwrit”. O polsko-hebrajskim bilingwizmie literackim w Izraelu (rekonesans). „Wielogłos” 2016, nr 2 (28), s. 99-123.

Traba R.: Procesy zbiorowego pamiętania i zapominania. Trzy przypadki i ich konsekwencje dla badania pamięci zbiorowej. W: Pamięć i afekty. Red. Z. Budrewicz, R. SENDy KA, R. Nycz. Warszawa 2014, s. 367-394.

Wolski P.: Myśli różne o ogrodach (koncentracyjnych). „Narracje o Zagładzie” 2016, nr 2, s. 7-11.

Żurek S.J.: Miriam Akavia. W: Leksykon kultury polskiej poza krajem od roku 1939. T. 1. Red. K. DyвсіAк, Z. Kudelski. Lublin 2000, s. 6-8.

Agnieszka Czyżak

Impossible Returns, Unavoidable Returns - Conventionality and Topicality in Miriam Akavia's Prose

Summary

The article contains reflections on Miriam Akavia's prose, with a special emphasis on her last book, written in 2005 and entitled Moje powroty [My Returns]. The main theme of Akavia's oeuvre was her biography: her childhood in Cracow before the Second World War, experiences during the occupation, the Holocaust, and her life in Israel after the war. Her method of writing 
was traditional; she used conventional and topical forms of expression as vehicles for expressing her attachment to such values as home, family, native land (along with her home town Cracow), and new adoptive country.

Key words: Holocaust, topos, convention, home, homeland 